\title{
PREVALENCE OF EIMERIA AND CRYPTOSPORIDIUM SPECIES IN CATTLE IN KAFR EL-SHEIKH PROVINCE
}

\author{
El-Seify, M. A. ; Desoukey, M. A. ; Khalafalla, R. E. and Sorour, S. Sh. \\ Departmeent of Parasitology, Faculty of Veterinay Medicin, Kafelsheikh University.
}

\begin{abstract}
This study was carried out, during 2011, to determine the prevalence of Eimeria spp. and Cryptosporidium spp. infecting cattle in Kafr ElSheikh province. Faecal samples $(n=698)$ were examined with flotation technique for Eimeria and modified Ziehl-Neelsen staining technique for Cryptosporidium spp. Oocysts. Eimeria spp. were in 28.94\% and Cryptosporidium spp. in $34.1 \%$. Eleven Eimeria spp. were identified and their prevalence were E.ellipsoidalis (52.5\%), E. cylindrica (34.2\%), E. bovis (31.2\%), E. zuernii (28.7\%), E. subspherica (19.8\%), E. alabmensis (6.9\%), E. canadensis (3\%), E. aubernensis (2\%), E. wyomingensis (1.5\%), E. brasiliensis (1\%) and E.bukidnonensis (1\%). Single infection of Eimeria species was found in $47.5 \%$ of the animals, while mixed infection of two and three species were found in 52.5\% of animals. Cattle are grouped according to their age into four groups: <3, 3-6, 6-9, >9 months. Eimeria spp. infection were detected in $31.4 \%, 37.1 \%, 26.7 \%$ and $19.0 \%$, while Cryptosporidium spp. infection was detected in 42.1\%. 41.4\%, 26.7\% and $19 \%$ of the calves in the respective age groups. Peak prevalence of Eimeria spp. and Cryptosporidium spp. infection was observed during winter $33.3 \%$ and $39.9 \%$, respectively. Eimeria and Cryptosporidium spp. infection were detected in $40.4 \%$ and $46.5 \%$ of diarrhoeic calves, respectively. There was higher prevalence of infection in diarrhoeic than in non-diarrhoeic calves.
\end{abstract}




\section{INTRODUCTION}

Coccidia are one of the most common intestinal parasites of large animals and are a cause of disease and production losses for animals in capacity (Fitzgerald, 1980 and Bürger, 1983).

Coccidiosis in cattle commonly occurs as subclinical and predisposing for great encomical losses due to reduced appetite, reduced body weight, impaired feed conversion, unthriftness, diarrhea, dysentery, anemia and increased susceptibility to other diseases (Bohrmann, 1991 and Thomas, 1994). The development of clinical coccidiosis in cattle mainly depend on factor like species of Eimeria, age of infected animal, number of oocysts ingested, presence of concurrent infections and type of production system and management practices (Ernst et al., 1984). More than 20 species of Eimeria has been described in cattle, yet only a few cause significant diseases; for examples, Eimeria bovis and Eimeria Zuernii cause sever mortality rates, whereas Eimeria auburnensis and Eimeria alabamensis are considered mildly pathogenic (Daugschies and Najdrowski, 2005).

Cryptosporidium parvum is the most frequently detected protozoan parasite in calves less than 3 weeks age (Moore and Zeman, 1991 and De la Fuente et al., 1999), where it considered being one of the main common causes of diarrhea at this age (Koudela and Bokova, 1997). However, Cryptosporidiosis should not only be considered from the perspective of animal health and production, its zoonotic character and the possibility that animals may act as a source of infection to humans, via foodstuff and water, should also be considered. Although the infection leads to few deaths, serious economic losses can occur due to costs involved in the treatment (De Graaf et al., 1999). Single infection 
with C. parvum is usually present in diarrheic calves; however, mixed infection with other pathogens exaggerates the problem (Vanopdenbosch et al., 1979).

Treatment of Cryptosporidiosis is not effective in cattle and its control measures are mainly based on preventive measures rather than treatment (Woods et al., 1996).

Despite its worldwide distribution and zoonotic relevance, there are still few publications concerning Cryptosporidium infection in cattle in Egypt as (Iskander et al., 1987; El-Sherif et al., 2000; El-Dessouky and El-Masry, 2005; El-Sherbini and Mohamed, 2006).

So, the aim of the present study was to determine:

- Prevalance and seasonal dynamics of Eimera spp. infecting cattle.

- Morphological identification of Eimeria spp. oocysts.

- Prevalence and seasonal dynamics of Cryptosporidium spp. oocysts.

\section{MATERIALS AND METHODS}

\section{Animals:}

In the present study 698 cattle of various ages, sex and breeds distributed in Sakha farm or private animals owned by farmers in Kafr El-Sheikh province were examined for the presence of some enteric protozoan parasites during the period extend from the beginning of January to December, 2011.

\section{Collection of faecal samples:}

A total of 698 faecal samples were collected from rectum or immediately after defecation from individual animal in polyethelyne sac and labeled according to age, sex, date of collection and locality. 
The faecal samples were transferred immediately to the laboratory of parasitology, Faculty of Vet. Med. Kafrelsheikh University.

\section{Preparation and examination of faecal samples:}

In the laboratory, the preparation and examination of the collected samples were conducted in the same day of collection.

The faecal samples were examined macroscopically three grades, solids, semi-solid and diarrhea.

\section{Laboratory examination of the collected faecal samples for Eimeria spp.:}

a. Flotation technique for detection of Eimeria species:

Examinations of faecal samples were done by concentration flotation technique according to Kruse and Pritchard (1982).

b. Sporulation of Eimeria species oocysts:

Eimeria oocysts from positively faecal samples were collected, purified and left to sporulate in $2.5 \%$ potassium dichromate according to William's (1969).

c. Identification of different Eimeria species oocysts:

The recovered species of Eimeria were identified according to the morphological characteristics of the Eimeria species infecting cattle as describe by Christensen (1941), Pellerdy (1965), Joyner et al. (1966) and Levine (1973).

5. Laboratory examination of the collected faecal samples for Cryptosporidium species:

Modified Ziehl-Neelsen staining technique was carried out according to Henriksen and Pohlenz (1981). 


\section{RESULTS}

Out of 698 examined faecal samples 28.94\% and 34.1\% were found positive for Eimeria spp. and Cryptosporidium spp., respectively. The rates of infection with Eimeria spp. and Cryptosporidium spp. were found higher in females (31.19\% and $34.17 \%$,respectively) than males (25.19\% and 33.97\%, respectively ) (Fig. 1).

Cattle group of 3-6 month old showed the highest rate of infection (37.1\%) with Eimeria spp. while the highest infection rate of Cryptosporidium spp. (42.1\%) was recorded among the cattle group of less than 3 month old. Figs. (2 and 3).

Concerning the seasonal dynamics of Eimeria spp. infection, the results in Fig. (4), revealed that cattle examined showed the highest rate of infection (33.3\%) in winter, followed by spring (29.1\%), summer (27.1\%) and autumn (26.6\%).

Concerning the seasonal dynamics of cryptosporidium spp. infection, the results in Fig. (5), revealed that cattle examined showed the highest rate of infection in winter (39.9\%), followed by spring (36.6\%), autumn (28.7\%) and summer (24.7\%).

Concerning the faecal consistency and its relation to Eimeria spp. and Cryptosporidium infection, the results in Fig. (6 \& 7), revealed that cattle examined showed the highest rate of infection in diarrheic faeces $40.4 \%$ and $46.5 \%$, respectively. 
El-Seify, M. A. et., al.

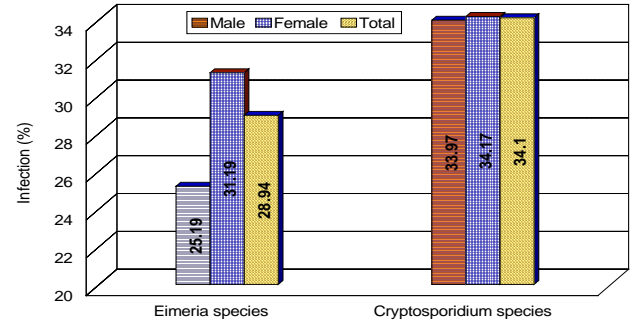

Figure (1): Prevalence of Eimeria and Cryptosporidium species in relation to the sex of examined cattle in Kafr El-Sheikh Province.

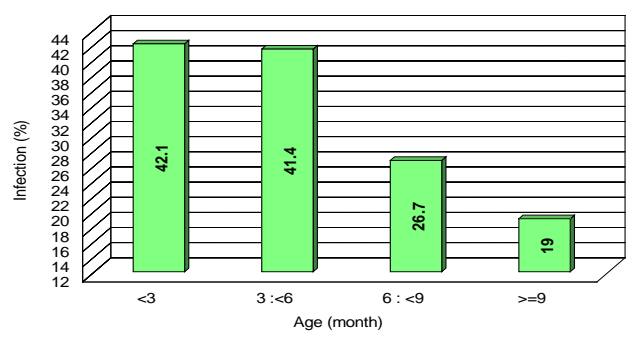

Figure (3) : Prevalence of Cryptosporidium species in relation to to age of examined cattle.

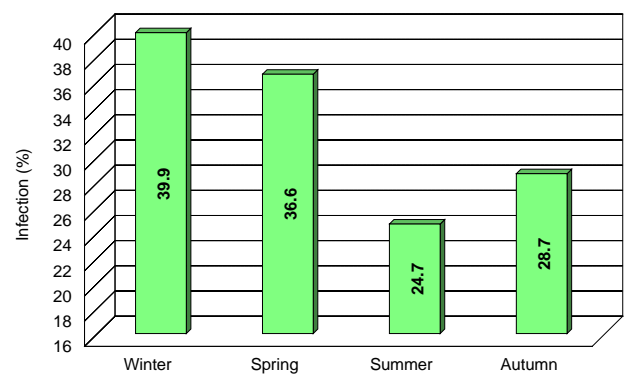

Figure (5) : Seasonal infection rate of Cryptosporidium species in cattle in Kafr El-Sheikh Province.

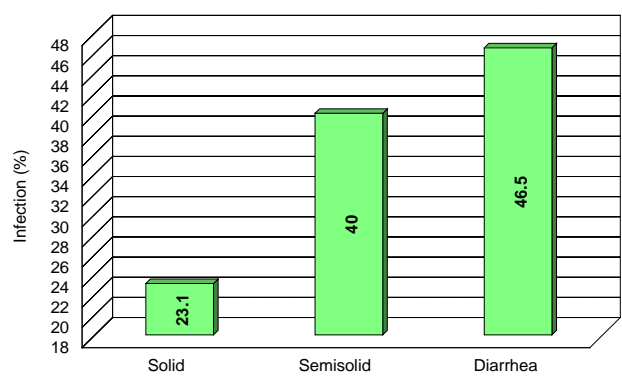

Figure (7) : The relation between the faecal consistency and Cryptosporidium species infection in cattle in Kafr El-Sheikh Province.

Kafrelsheikh Vet. Med. J. Vol. 10 No. 2 (2012)

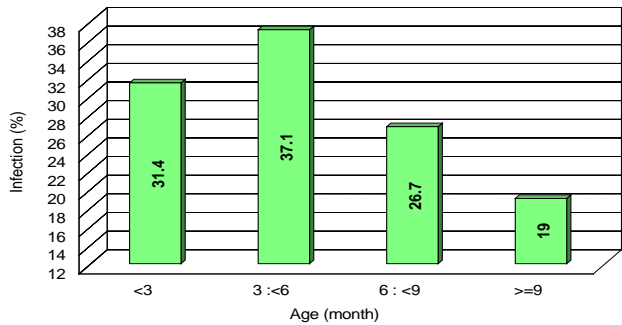

Figure (2): Prevalence of Eimeria species in relation to age of examined cattle.

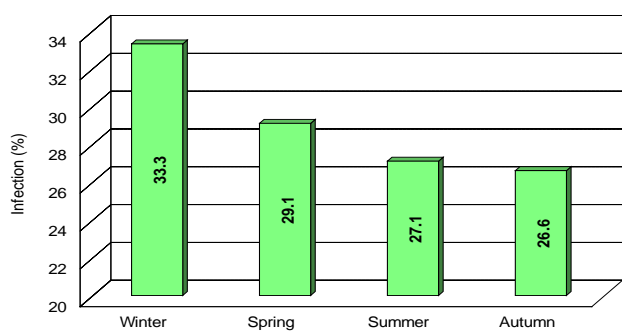

Figure (4) : Seasonal infection rate of Eimeria species in cattle in Kafr El-Sheikh Province.

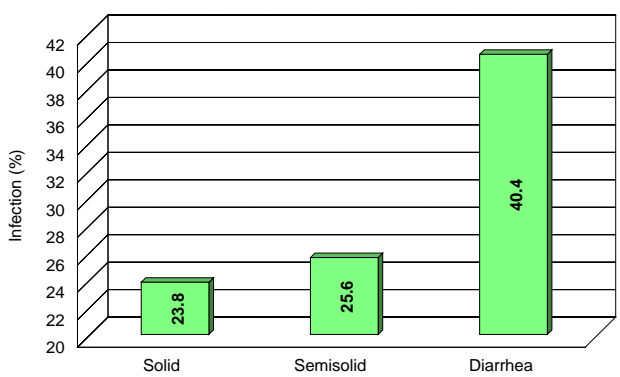

Figure (6) : The relation between the faecal consistency and Eimeria species infection in cattle in Kafr El-Sheikh Province.

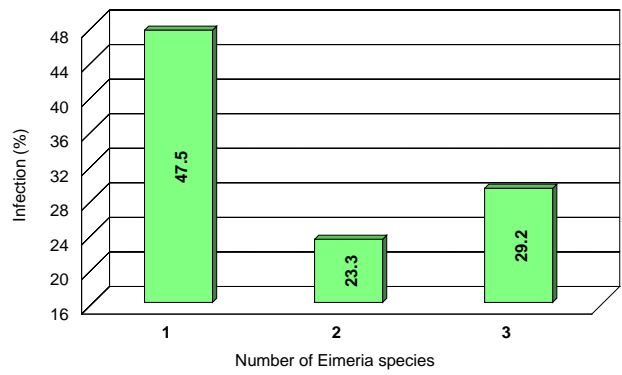

Figure (10): The percentage of Eimeria species in infected cattle. 
Prevalence Of Eimeria And Cryptosporidium Species In Cattle In...

Eleven Eimeria spp. were identified and their prevalence were $E$. ellipsoidalis (52.5\%), E. cylindrica (34.2\%), E. bovis (31.2\%), E. zuernii (28.7\%), E. subspherica (19.8\%), E. alabmensis (6.9\%), E. canadensis (3\%), E. aubernensis (2\%), E. wyomingensis (1.5\%), E. brasiliensis (1\%) and E. bukidnonensis (1\%) (Fig.8, Fig.9 and Table1). Single infection of Eimeria species was found in $47.5 \%$ of the animals. Mixed infection of two and three species were found in $52.5 \%$ of animals, Fig. (10) and Table (2).

Table (1): Prevalence of single and mixed infection of Eimeria species in cattle in Kafr El-Sheikh Province.

\begin{tabular}{|c|c|c|c|c|c|c|}
\hline \multirow{2}{*}{ Species } & \multicolumn{2}{|c|}{ Single infection } & \multicolumn{2}{|c|}{ Mixed infection } & \multicolumn{2}{|c|}{ Total infection } \\
\hline & No & $\%$ & No & $\%$ & No & $\%$ \\
\hline Total & 96 & 47.5 & 106 & 52.5 & 202 & 28.94 \\
\hline E. ellipsoidalis & 21 & 10.4 & 85 & 42.1 & 106 & 52.5 \\
\hline E. cylindrica & 6 & 3.0 & 63 & 31.2 & 69 & 34.2 \\
\hline E. bovis & 19 & 9.4 & 44 & 21.8 & 63 & 31.2 \\
\hline E. zuernii & 15 & 7.4 & 43 & 21.3 & 58 & 28.7 \\
\hline E. subspherica & 4 & 2.0 & 36 & 17.8 & 40 & 19.8 \\
\hline E. alabamensis & 14 & 6.9 & & & 14 & 6.9 \\
\hline E. canadensis & 6 & 3.0 & & & 6 & 3.0 \\
\hline E. aubernensis & 4 & 2.0 & & & 4 & 2.0 \\
\hline E. wyomingensis & 3 & 1.5 & & & 3 & 1.5 \\
\hline E. brasiliensis & 2 & 1.0 & & & 2 & 1.0 \\
\hline E. bukidnonensis & 2 & 1.0 & & & 2 & 1.0 \\
\hline
\end{tabular}

$\overline{\text { Kafrelsheikh Vet. Med. J. Vol. } 10 \text { No. } 2 \text { (2012) }}$ 
El-Seify, M. A. et., al.

Table (2): Prevalence of mixed Eimeria species in cattle in Kafr El-Sheikh Province.

\begin{tabular}{|c|c|c|}
\hline \multirow{2}{*}{ Species } & \multicolumn{2}{|c|}{ Infected cattle } \\
\hline & No & $\%$ \\
\hline Total & 106 & 52.5 \\
\hline E. ellipsoidalis + E. cylindrica & 26 & 12.9 \\
\hline E. subspherica + E. cylindrica & 12 & 5.9 \\
\hline E. subspherica + E. zuernii & 9 & 4.5 \\
\hline E. ellipsoidalis + E. zuernii + E. bovis & 19 & 9.4 \\
\hline E. ellipsoidalis + E. cylindrical + E. bovis & 25 & 12.4 \\
\hline E. ellipsoidalis + E. subspherica + E. zuernii & 15 & 7.4 \\
\hline
\end{tabular}



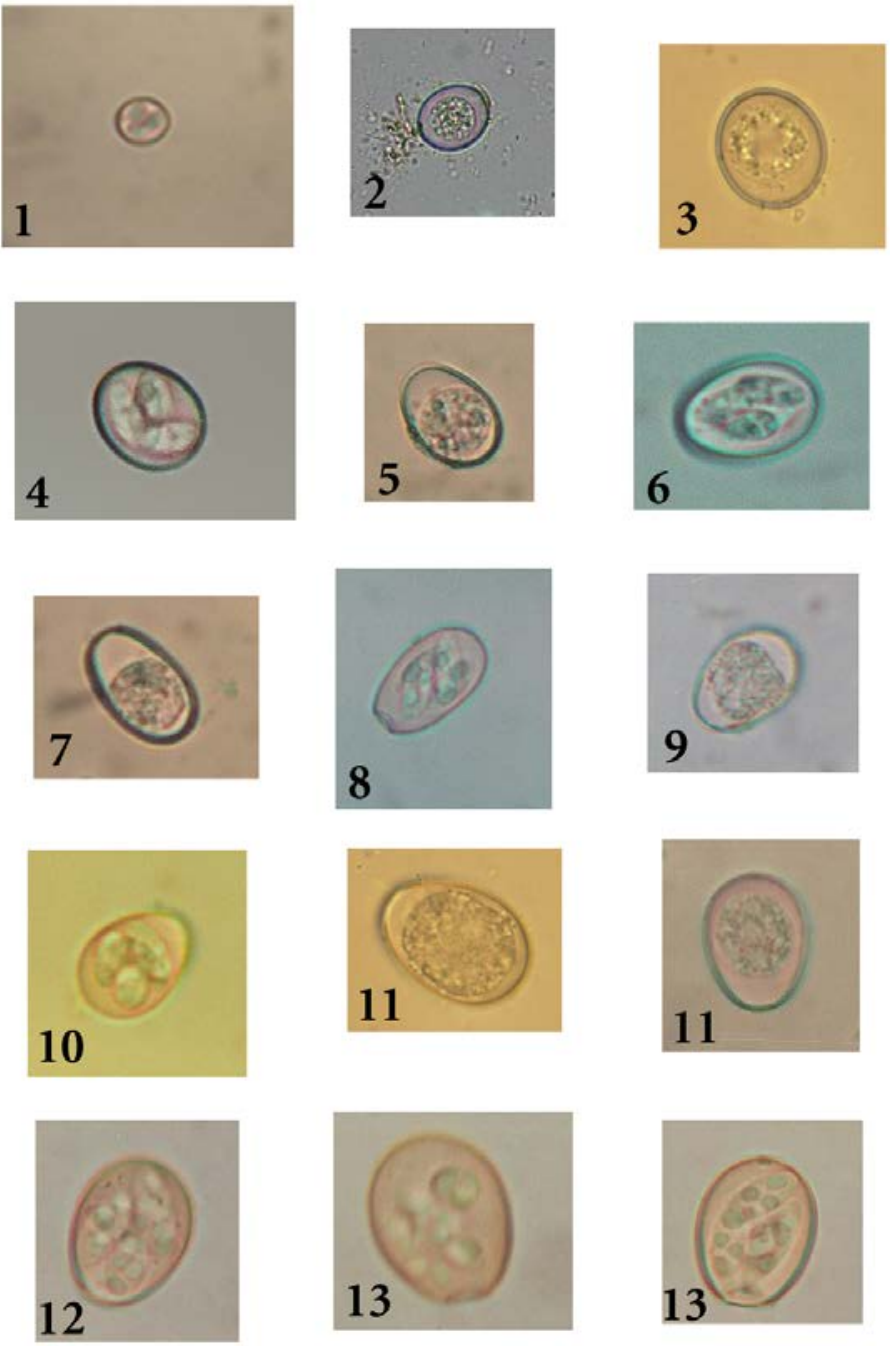

\section{Figure (8):}

1. Sporulated oocyst of E. subspherica X 40

3. Unsporulated oocyst of E. zuernii X 100

5. Unsporulated oocyst of E. ellipsoidalis X 100

7. Unsporulated oocyst of E. cylindrica X 100

9. Unsporulated oocyst of E. alabamensis X 100

11. Unsporulated oocyst of E. bovis X 100

13. Sporulated oocyst of E. canadensis X 40
2. Unsporulated oocyst of E. subspherica X 100

4. Sporulated oocyst of E. zuernii X 100

6. Sporulated oocyst of E. ellipsoidalis X 100

8. Sporulated oocyst of E. cylindrica X 100

10. Sporulated oocyst of E. alabamensis X 100

12. Unsporulated oocyst of E. bovis X 100

$\overline{\overline{\text { Kafrelsheikh Vet. Med. J. Vol. } 10 \text { No. } 2 \text { (2012) }}}$ 
Cryptosporidium oocysts were identified by staining with modified Ziehl-Neelsen technique, Fig. (9), the oocysts appeared round or spherical in shape. The wall was smooth and the oocysts appeared as densely stained red bodies on green background with accentric dot or vacules.

The dimensions of the detected oocysts were 2.8-5 x 3.2-5.8 $\mu \mathrm{m}$ with an average of $3.99 \times 4.7 \mu \mathrm{m}$.
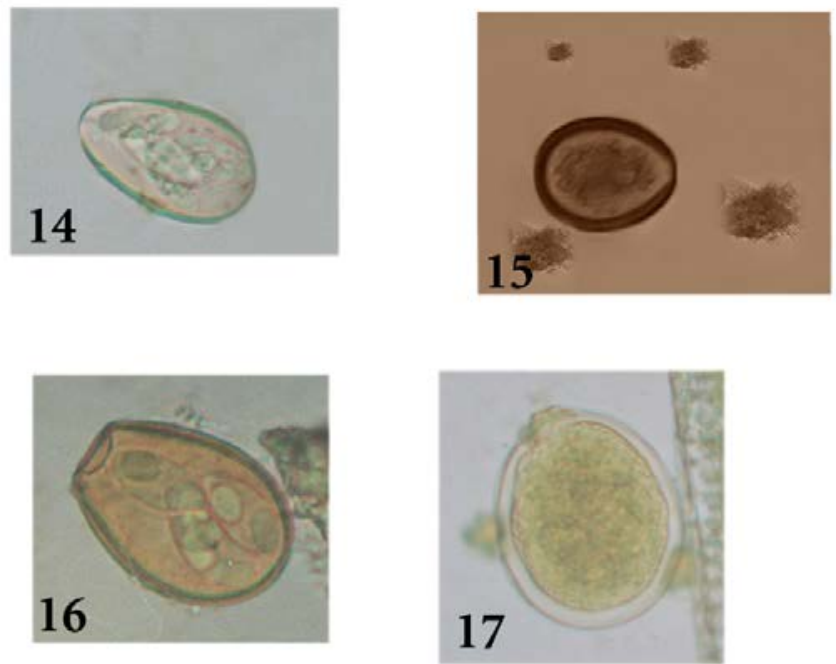

Figure (9):

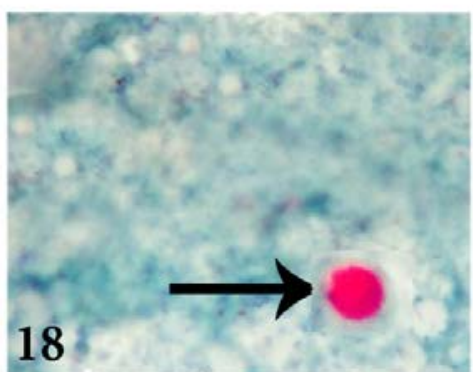
14. Sporulated oocyst of E. aubernensis X 40
15. Unsporulated oocyst of E. bukidnonensis X 10
16. Sporulated oocyst of E. wyomingensis X 40
17. Unsporulated oocyst of E. brasiliensis X 10
18. Cryptosporidium oocyst stained with modified Zeihl- Neelsen stain X 100 


\section{DISCUSSION}

The result of the present study revealed that, $28.94 \%$ from the examined cattle found to be infected with Eimeria species. These results was similar to that obtained by Waruiru et al. (2000) in Kenya, Hasan et al. (2010) in Iraq and Toaleb et al. (2011) in Egypt. On the other hand, the result in the present study disagreed with those of Arslan and Tüzer (1998) in Turkey and Lassen et al. (2009) in Estonian. This variation was most likely attributed to the differences in agro-ecology management, and husbandry practices of the study animals in different countries.

The obtained results showed that the prevalence of Eimeria infecting female cattle was higher than that among the male one where the infection rates reached $31.19 \%$ and $25.19 \%$, respectively as also recorded previously by Rehman et al. (2011). This result might be attributed to the female animal usually subjected to many stress condition as pregnancy, lactation, calving and little managemental care. Also most of males were breed for fattening purpose under good hygienic conditions.

The results in this study clarified that young age of cattle were more susceptible for Eimeria infection than old one. The most susceptible age was 3-6 month as the percentage of infection was 37.1\% as it mentioned before by Lentze et al. (1999), Daugschies and Najdrowski (2005) and Lassen et al. (2009). These results could be attributed to calves age 3 months discontinue a milk diet and passive immunity drops. While the old animals are likely to have a developed immune system and experienced Eimeria infections. 
The present data recognized that winter season was the most suitable season for Eimeria infection as the infection rate of Eimeria reached to $33.3 \%$ and it was followed by winter, spring, autumn and finally the summer season where the infection rates were $29.1 \%, 27.1 \%$ and 26.6\%, respectively. These results agreed with El-Sherif and Aboelhadid (2005) in Egypt and disagreed with that of Vercrysee (1982) who stated that no seasonal fluctuation in the prevalence of Eimeria species. From the present results, it was concluded that Eimeria infection was more abundant and common during winter season, this might be attributed to a good environmental condition during this season as good weather with moderate temperature that was suitable for the oocyst and accelerate its sporulation process.

The present data recognized that Eimeria infection in relation to consistency of faeces was higher in diarrheic than non diarrheic calves. This was in line with the observations of Chibuanda et al. (1997); Svensson (2000) and Kennedy (2001), all of which stated that development of clinical disease depends on the number of oocysts ingested.

Eimeria species identified in the present study have been previously reported by Abebe et al. (2008), Klockiewiez et al. (2007) and Lassen et al. (2009). E. ellipsoidalis, E. cylinderica, E. bovis and E. zuernii were recorded as the highest prevalent coccidian species which is accordance with reports of El-Sherif and AboEl-Hadid (2005).

The results in this study recognized the prevalence of Cryptosporidium species among cattle, as its total prevalence was $34.1 \%$, these results were nearly similar to those obtained by Huetink et al.

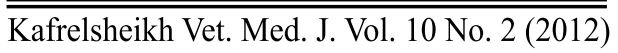


(2001) in the Netherlands and Watanabe et al. (2005) in Taiwan. These results were lower than that obtained by Silverlas et al. (2010) in Sweden and Bhat et al. (2012) in India. The variation between the different prevalence rates of the disease may be attributed to the system of rearing and management in addition to the level of hygienic measures applied. The other workers examined only diarrhoeic cases or apparently healthy or examination of neonatal or un-weaned animal only. While in the present study, examination was carried out in cattle at different ages, diarroeic and apparently health.

Regarding to the age, the present results recognized that calves less than 3 months were more susceptible for Cryptosporidial infection than the adult ones (9 month old)where the infection rate was $42.1 \%$ and 19.0\%, respectively. These results agreed with those of De La Fuente et al. (1999) and Wade et al. (2000). On contrary, Cryptosporidiosis was recorded in older bovine calves (Maddox-Hyttel et al., 2006). These results could be attributed to the presence of calves with their dams especially during the lactation period where the adult act as carrier for Cryptosporidium oocysts or might be due to the underdevelopment immunity of calves to the parasitic infections.

A significant association between the season and the prevalence of Cryptosporidium spp. infection was recorded in this study. Winter recorded the highest prevalence (39.9\%), while summer recorded the lowest $(24.7 \%)$. It is suggested that the prevalence of infection by Cryptosporidium spp. is not only related to the presence of calves at risk but also related to the presence of the suitable climatic condition for viability and spread of the parasite. In winter, the temperature in our 
locality is suitable for viability, survival and survival of Cryptosporidium oocysts. Similar findings were recorded by Tzipori (1983) and Lefay et al. (2000). These results were supported by Anderson (1986) who found that warm temperature of 18 to $29^{\circ} \mathrm{C}$, had been partially responsible for loss of the infectivity. However, Garber et al. (1994) attributed the high prevalence of Cryptosporidiosis in winter to the presence of large number of calves at risk a result of concentration of calving in winter months. On contrary, In California, Atwill et al. (1999) found that calves were at high risk of contracting infection by Cryptosporidium spp. during May month and they attributed this to the greatest contact with the source of infection, lowering animal resistance of environmental conditions that might favor transmission of the infection during this month. Contrary to all recorded results, absence of seasonality in the presence of Cryptosporidium infection has been described (Wade et al., 2000 and Castro-Hermida et al., 2002).

In regard to clinical signs, as previously mentioned, the main clinical sign of Cryptosporidiosis is diarrhea. The infection rate in diarrheic calves was $46.5 \%$. This result came in accordance with carried out in cattle by Atwill et al. (1999) and Castro-Hermida et al. (2002). Coexistence of C. parvum, rotavirus, corona virus and Salmonella, among others, in calves of less than one month of age, with diarrhea was recorded (De la Fuente et al., 1999).

The morphological features of Cryptosporidium oocysts as detected by modified Ziehl-Neelsen technique reported in the present study were similar to those described by Henricksen and Pohlenz (1981). 


\section{REFERENCES}

- Abebe, R.; Wossene, A. and Kumsa, B. (2008). Epidemiology of Eimeria infections in calves in Addis Ababa and Debre Zeit dairy farms. Ethopia Int. J. Appl. Res. Vet. Med., 6: 24-30.

- Anderson, B. C. (1986). Patterns of shedding of cryptosporidial oocysts in Idho calves. J. Am. Vet. Med. Assoc., 178: 982-984.

- Arslan, M. O. and Tüzer, E. (1988). Prevalence of bovine eimeriosis in Thracia, Turkey. Tr. J. of Veterinary and Animal Science, 22: $161-164$.

- Atwill, E. R.; Johnson, E.; Klingborg, D. J.; Veserat, G. M.; Markegard, G.; Jensen, W. A.; Pratt, D. W.; Delmas, R. E.; George, H. A.; Forero, L. C.; Phillips, R. L. Barry, S. J. ; McDougald, N. K.; Gildersleeve, R. R. and Frost, W. E. (1999). Age geographic and temporal distribution of fecal shedding of cryptosporidium parvum oocysts in cow-calf herds. American Journal of Veterinary Research, 60: 420-425.

- Bhat, S. A.; Juyal, P. D. and Singla, L. D. (2012). Prevalence of cryptosporidiosis in neonatal buffalo calves in Ludhiana District of Punjab, India. Asian Journal of Animal and Veterinary Advances, 7(6): 512-520.

- Bohrmann, R. (1991). Toltrazuri treatment of calves in a natural outbreak of coccidiosis. Dtsch Tieraerztl Wochenschr, 98: 343-345.

- Bürger, H. J. (1983). Eimeria-infectionen beim Rind. Berl. Munch. Tieraerztl. Wochenschr. Vol. 96: 350-357. 
- Castro-Hermida, J. A.; Gonzalez-Losada, Y. A. and Ares-Mazas, E. (2002). Prevalence of and risk factors involved in the spread of neonatal bovine cryptosporidiosis in Galicia (NW Spain). Veterinary Parasitology, 106: 1-10.

- Chibuanda, R. T.; Muhairw, A. P.; Kambarage, D. M.; Mtambo, M. M. A.; Kusiluka, L. IJ. M. and Kazala, R. R. (1997). Eimerosis in dairy cattle farms in Morogoro municipality of Tanzania. Prev. Vet. Med., 31: 191-197.

- Christensen, J. F. (1941). The oocysts of coccidian from domestic cattle in Alabama (USA) with description of two new species. J. Parasit., 27: 203-220.

- Daugschies, A. and Najdrowski, M. (2005). Eimeriosis in cattle: Current understanding. J. Vet. Med., 52: 417-427.

- De Graff, D. C.; Vanopdenbosch, E.; Ortega-Mora, L. M.; Abbassi, H. and Peeters, J. E. (1999). A review of the importance of cryptosporidiosis in farm animals. International Journal of Parasitology, 29: 1269-1287.

- De la Fuente, R.; Luzon, M.; Ruiz-Santa-Quiteria, J. A.; Garcia, A. ; Cid. D.; Orden, J. A.; Gracia, S.; Sanz, R.; Gomez-Bautista, M. (1999). Cryptosporidium and concurrent infections with other major enterpathogens in 1-30-day old diarrheic dairy calves in central Spain. Veterinary Parasitology, 80: 179-185.

- El-Dessouky, S. A. and El-Masry, N. M. (2005). Effect of cryptosporidium parvum infection on the haematology and blood chemistry of buffalo calves with special reference to the prevalence of infection in adult buffaloes. Assuit Veterinary Medical Jornal, 51: 105-123. 
- El-Sherbini, G. T. and Mohamed, K. A. (2006). Zoonotic cryptosporidiosis in man and animal in farms, Giza Governorate, Egypt. Journal of the Egyptian Society of Parasitology 36: 49-58.

- El-Sherif, A. M.; Abdel-Gawad, M. A.; Lotfy, H. S.; Shokier, K. A. M. (2000). Impact of gastrointestinal nematodes and some enteric protozoal affections on the health of buffalo calves. Assuit Veterinary Medical Journal, 43: 260-270.

- El-Sherif, A. M. and AboEl-Hadid, S. M. (2005). Epizootological investigation about different internal parasitic affections among cattle calves in Beni-suif Governorate, 6: 261-24.

- Ernst, J. V.; Ciordia, H. and Stuedemann, J. A. (1984). Coccidia in cows and calves on pasture in South Georgia (USA). Vet. Parasitol., 15: $21-221$.

- Fayer, R.; Santin and Xiao, L. (2005). Cryptosporidium bovis sp. (Apicomplexa: cryptosporidae) in cattle (Bos Taurus). Journal of Parasitology, 91: 624-629.

- Fitzgerald, P. R. (1980). The economic impact of coccidiosis in domestic animals. Adv. Vet. Sci. Comp. Med. Vol. 24: 121-143.

- Garber, L. P. ; Salman, M. D. ; Hurd, H. S. ; Keefe, T. and Schater, J. L. (1994). Potential risk factors for cryptosporidium infection in dairy calves. Journal of American Veterinary Medical Association, 205: 86-91. 
- Hasan, M. H.; Butty, E. T. and Al-Taee, A. F. (2010). A study on intestinal protozoa in calves in Ninevah Governorate. Iraq Journal of Veterinary Science, 24(2): 163-167.

- Henricksen, S. A. and Pohlenz, J. F. (1981). Staining of cryptosporidium by a modified Ziehl-Neelsen Technique. Act. Vet. Sc., 22(1): 594-596.

- Huetink, R. E. C.; Van der Giessen, J. W. B.; Noordhuizen, J. P. and Ploeger, H. W. (2001). Epidemiology of cryptosporidium spp. and Giardia duodenalis on a dairy farm. Veterinary Parasitology, 102: 53-67.

- Iskander,A. R.;Tawfeek, A.and Farid, A. F. (1987). Cryptosporidial infection among buffalo calves in Egypt. Indian Journal of Animal Science, 57: 1057.

- Joyner, L. R.; Norton, C. C.; Davies, S. F. M. and Watkins, C. V. (1966). The species of coccidian occurring in cattle and sheep in the South-West of England. Parasitology, 56: 531-541.

- Kennedy, M. J. (2001). Coccidioses in cattle. In : AGRIFACTS: Edmonton, Alberta, Canada, Alberta Agriculture, Food and Rural Development, Government of Alberta.

- Klockiewiez, M.; Kaba, J.; Tomezuk, K.; Janecka, E.; Sadzikowski, A. B.; Rypula, K.; Studzinska, M. and Malecki-Tepicht, J. (2007). The epidemiology of calf coccidiosis (Eimera spp.) in Poland. Parasitol. Res., 101: 121-128. 
- Koudela, B. and Bokova, A. (1997). The effect of cotrimoxzole on experimental cryptosporidium parcum infection in kids. Veterinary Research, 28: 405-412.

- Kruse, G. O. W. and Pritchard, M. H. (1982). The collection and preservation of animal parasite. University of Nebraska Press- Lincoln and London.

- Lassen, B.; Viltrop, A.; Raaperi, K. and Jarvis, T. (2009). Eimeria and cryptosporidium in Estonian dairy farms in regard to age, species and diarrhea. Vet. Parasitol., 166(3-4): 212-219.

- Lefay,D.; Naciri, M.; Poirier,P.and Chermette, R.(2000). Prevalence of cryptosporidium infection in calves in France. Veterinary Parasitology, 89: 1-9.

- Lentze, T.; Hofer, D.; Gottstein, B. ; Gaillard, C. and Busato, A. (1999). Haeufigkeit und bedeutung von endoparasiten bei kaelbern in Schweizer Mutter-Kuhbetrieben. Dtsch. Tieraerzt. Wochenschr. 106: 269-308.

- Levine, N. D. (1973). Protozoan parasites of domestic animals and man. Second Edition. Burgess publishing company, Minneapolis, Minnesota.

- Maddox-Hyttel, C.; Langkjaer, R. B.; Enemark, H. L. and Vigre, H. (2006). Cryptosporidium and Giardia in different age groups of Danish cattle and pigs-Occurrence and management associated risk factors. Veterinary Parasitology, 141: 48-59. 
- Moore, D. A. and Zeman, D. H. (1991). Cryptosporidium in neonatal calves 277 cases (1986-1987). Journal of American Veterinary Medical Association, 198: 1969-1971.

- Pellerdy, L. P. (1965). Coccidia and coccidiosis. Akod.Kiado, Budapest. Hungary: 657.

- Rehman, T. U.; Khan, M. N.; Sajid, M. S.; Abbas, R. Z.; Arshad, M.; Iqbal, Z. and Iqbal, A. (2011). Epidemiology of Eimeria and associated risk factors in cattle of district Toba Tek Singh, Pakistan. Parasitol. Res., 108: 111-1177.

- Silverlas, C.; De Verdier, K.; Emanuelson, U.; Mattsson, J. G. and Bjorkman, C. (2010). Cryptosporidium infection in herds with and without calf diarrhoeal problems. Parasitol Res., 107: 1435-1444.

- Svensson, C. (2000). Excretion of Eimeria alabamensis oocysts in grazing calves and young stock. J. Vet. Med., 47: 105-110.

- Thomas, H. S. (1994). Coccidiosis in calves. The Cattleman, 81: 21-32.

- Toaleb, N. I.; El-Moghazy, F. M. and Hassan, S. E. (2011). Diagnosis of Eimeriosis in cattle by ELISA using partially purified antigen.w World Applied Science Journal, 12(1): 33-38.

- Tzipori, S. R. (1983). Cryptosporidiosis in animals and humans. Microbiological Review, 4: 84-96.

- Vanopdenbosch, E.; Wellemans, G.; Dekegel, X. and Strobbe, R. (1979). Neonatal calf diarrhea: A complex etiology, VI Dierg Tijdschr. 48: 512-526. 
- Vercrysee, $\boldsymbol{J}$. (1982). The coocidia of sheep and goats in Senegal. Vet. Parasitol., 10: 297-306.

- Wade, S. E.; Mohammed, H. O. and Shaaf, S. I. (2000). Prevalence of Giardia sp., cryptosporidium parvum and cryptosporidium muris (C. andersoni) in 109 dairy herds in five countries of southeastem New York. Veterinary Parasitology, 93: 1-11.

- Waruiru, R. M.; Kyvsgaard, N. C.; Thamsborg, S. M.; Nansen, P.; Rogh, H. O.; Munyua, W. K. and Gathuma, J. M. (2000). Prevalence and intensity of hemline and coccidial infections in dairy cattle in central Kenya. Veterinary Research Communications, 24(1): 39-55.

- Watanabe, Y.; Yang, C. H. and OOi, H. K. (2005). Cryptosporidium infection in livestock and first identification of cryptosporidium parvum genotype in cattle feces in Taiwan. Parasitol. Res., 97(3): 238-242.

- William's, R. B. (1969). The persistence of drug resistance in strain of Eimeria species in broiler chicken following a change of coccidiostate. Res. Vet. Sci., 10: 490-492.

- Woods, K. M.; Nesterenko, M. V. and Upton, S. J. (1996). Efficacy of 101 antimicrobials and other agents on the development of cryptosporidium parvum in vitro. Annal. Tropical Medicine Parasitology, 90: 603-615. 
معدلات إصابة الأبقار بالايميريا و الكربتوسبورديم في محافظة كفر الثيخ

أظهـرت نتـائج الدراســة الحاليـة ومـن خـلال فحص 698 عينـة بـراز أبقـار جمعـت مـن محافظة كفر الثيخ خلال عام 2011م لتحديد الإصـابة بالايميريا عن طريق (التعويم بمحلول الملح المركز ) والكربتوسبورديم عن طريق صبغة زيـل نيلسن. وجد أن نسب الإصـابة الكلية بالايميريا 28.94\% والكربتوسبورديم 34.1\% وقد تم تثخيص 11 نوع من الايميريا كالتالي: E.ellipsoidalis (52.5\%), E. cylindrica (34.2\%), E. bovis (31.2\%), E. zuernii (28.7\%), E. subspherica (19.8\%), E. alabmensis (6.9\%), E. canadensis (3\%), E. aubernensis (2\%), E. wyomingensis (1.5\%), E. brasiliensis (1\%) and E.bukidnonensis (1\%).

وقد وجـد أن الإصـابة الفرديـة بنوع واحـد مـن الايميريـا كانــ 47.5\% بينــا الإصـابة المختلطة بنوعين أو ثلاثة كانت 52.5\%.

وقد تـم تصـنيف الأبقـار حسب العمـر إلـي أربـع مجموعـات أقـل مـن ثلاثـة شـهور ، 3 31.4\%, 6 شهور ، 6-9 ، وأكبر من 9 شهور وكانت نسب الإصابة بالايميريا كالتالي

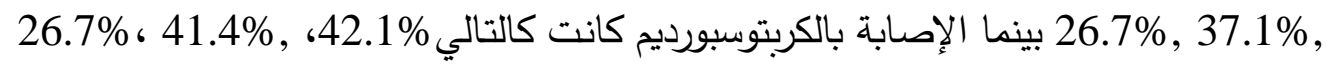
$.19 \%$ و

وقد لوحظ ارتفاع نسبة الإصـابة بالايميريا 33.3\% والكربتوسبورديم 39.9\% في فصل الثتاء وقد وجد أن الإصـابة بالايميريـا والكربتوسبورديم في الحيوانات المسهلة أعلي من غيرها فكانت الإصابة بالايميريا 40.4\% والكربتوسبورديم 46.5\%. 